UDC 623.7.014-519.027.6(045)

DOI:10.18372/1990-5548.64.14864

${ }^{1}$ M. F. Tupitsin,
${ }^{2}$ I. O. Stepanenko

\title{
ROTATIONALLY-CATAPULT SYSTEM FOR UNMANNED AERIAL VEHICLE TAKE-OFF AND LANDING
}

\author{
${ }^{1,2}$ Aviation Computer-Integrated Complexes Department, National Aviation University, Kyiv, Ukraine \\ E-mails: 'tupitsyn2@gmail.com, ${ }^{2}$ STEPANENKO.iLay@gmail.com
}

\begin{abstract}
In the article is proposed the design of the rotational-catapult system for take-off and landing of unmanned aerial vehicles and determined the algorithm of its functioning. The features of the rotationallycatapult system operation with horizontal and inclined position of the catapult rotational disk are considered in detail. The peculiarities of the rotationally-catapult system functioning include the fact that, on the one hand, the wing span of the unmanned aerial vehicle is limited by the size of the rotating disk of catapult, and an increase in the size of which leads to increased consumption of materials, energy costs, and etc. On the other hand, structural elements of the wing and the unmanned aerial vehicle as a whole, depending on their distance from the rotation axis of catapult and their spatial position, will be affected by centripetal forces of different magnitude and direction, which can damage these elements. In the work an expression for the directing cosines of the unit centripetal acceleration vector is obtained for steady rotational motion of the catapult at its arbitrary inclined position, which makes it possible to simplify the calculation of the unmanned aerial vehicle dynamics motion. The article also provides an example of calculating the landing of unmanned aerial vehicle with characteristics an "Orbiter 3" onto a rotating catapult disk.
\end{abstract}

Index Terms - Rotatable catapult; rotating disk of catapult; rotationally-catapult system.

\section{INTRODUCTION}

At decreasing a distance of take-off and landing for unmanned aerial vehicles (UAVs) the possibilities of them using are flared. Just there are many means of take-off and landing for the UAVs of aircraft schematic view.

The essence of the most famous method, which allows doing to do both takeoff and landing of an aircraft, is to transform the design of the engine and / or an airframe, which changes the angle of inclination of the engines thrust relative to the aircraft. In this case take-off and landing is implemented vertically and a flight - horizontally. But this method has a series of disadvantages, namely, owing to additional mechanisms is increased the UAV weight and is decreased flight time, load capacity and reliability.

The other method, which is adequate only for the UAV take-off, to use assistive devices: catapults, rocket boosters and so on. The series of such devices is shown in Table I.

The scheme no. 3 is the most rational constructive decision for UAV take-off, as it is shown in research [1].

In this paper is also described scribed the device of catapult, for which a patent [2] is received.

This catapult device involves of gear for initial velocity determination and direction of the UAV flight at its separation from catapult. General view of catapult with UAV is shown in Fig. 1.
TABLE I. Block DiAgRAMS OF THE MECHANISMS of StARTING DEVICES

\begin{tabular}{|l|l|l|}
\hline No. & \multicolumn{1}{|c|}{ Starting device } & Starting device scheme \\
\hline 1 & $\begin{array}{l}\text { With translational } \\
\text { movement of UAV }\end{array}$ \\
\hline 2 & $\begin{array}{l}\text { With gyration of the } \\
\text { UAV around } \\
\text { horizontal axis }\end{array}$ \\
\hline 3 & $\begin{array}{l}\text { With gyration of the } \\
\text { UAV around } \\
\text { vertical axis }\end{array}$ \\
\hline 4 & $\begin{array}{l}\text { With gyration of the } \\
\text { UAV around } \\
\text { vertical axis } \\
\text { involving of } \\
\text { catapult engine }\end{array}$ \\
\hline 5 & $\begin{array}{l}\text { With linear guiding } \\
\text { ways and additional } \\
\text { inertial elements }\end{array}$ \\
\hline 6 & $\begin{array}{l}\text { With linear guiding } \\
\text { ways and dampers }\end{array}$ \\
\hline
\end{tabular}




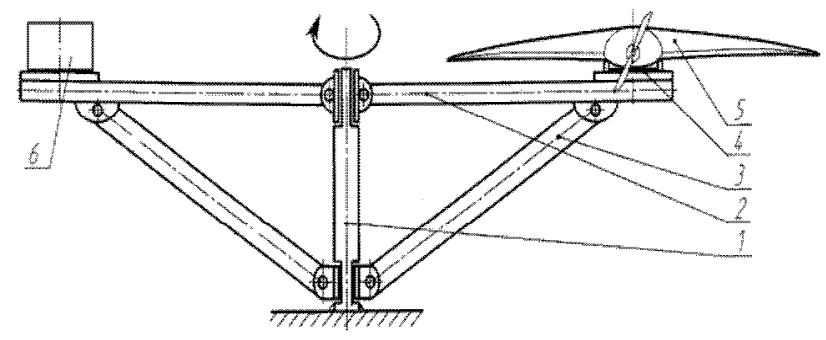

Fig. 1. General view of catapult with UAV and counter weight: 1 is the vertical axis of the catapult rotation; 2 is the double-arm lever; 3 are knee rafters; 4 is the platform; 5 is the UAV; 6 is the counter-weight

Considerable disadvantage such catapult is that after UAV launching with help of catapult for its landing it is necessary additional gadget.

Rotatable catapult (RC) [3] for launching and landing aircraft has complex construction, which is including of moving platform on catapult, slide-rails, damper and other. However, its efficiency and fitness for work is not sufficiently researched.

\section{PROBlEM STATEMENT}

In the article is set to modernize of $\mathrm{RC}$ construction [3] and appraise its capacity for work.

For task solution it is necessary:

- determine list of the RC functional elements and to carry out some improvements to its construction;

- scribe an algorithm of the RC work;

- determine the magnitude and direction of the forces acting on the UAV at different variants its landing on the $\mathrm{RC}$;

- estimate the stopping distance of the UAV during landing upon RC.

\section{PROBlem SOLUTION}

For task solution it is supposed the automatized rotationally-catapult system (RCS), which has two main functional elements (Fig. 2):

1) operating mechanism, which has rotating disk of catapult (RDC) with an engine for its and, as minimum, three free-running lifting jacks (in Fig. 2 is shown four ones) with the engines and swing supports on them ends;

2) control unit, which sends commands from operator to operating mechanism and executing the keeping track of an performance accuracy these commands; and operator.

The rotationally-catapult system at UAV take-off works in the following way.

The rotary disk of the catapult 3 with a radius $R$ is located in a horizontal position (Fig. 3), in which the axis of the support $1 \mathrm{RDC}$ is in a vertical position.

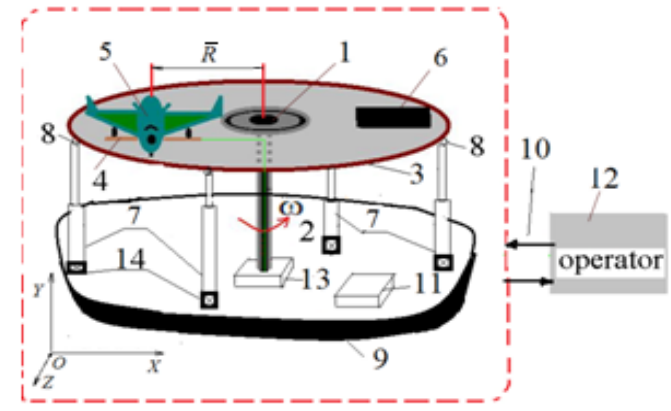

Fig. 2. The automatized RCS: 1 is the catapult fulcrum axis; 2 is the fulcrum bearing; 3 is the RDC; 4 is the UAV retaining pin at take-off; 5 is the UAV; 6 is the balancer;

7 are lifting jacks; 8 are swing supports; 9 is the foundation; 10 is the intercoupler; 11 is the control unit; 12 is the operator; 13 is the RDC engine; 14 are lifting jacks engines

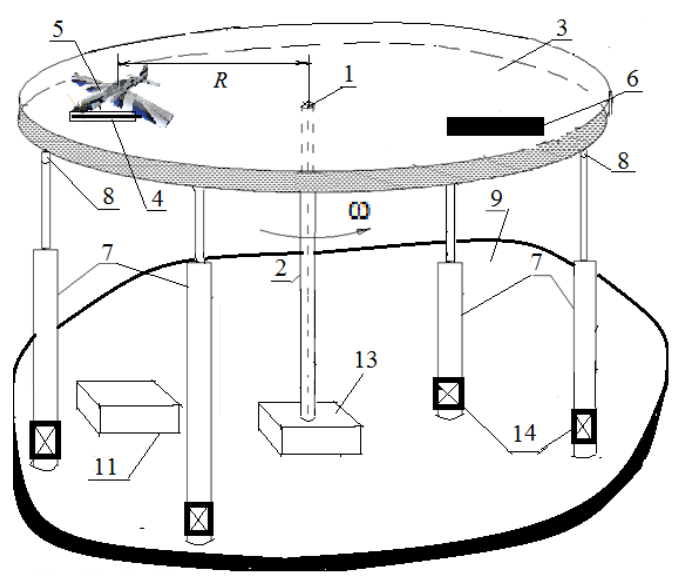

Fig. 3. The horizontal position of the RDC at take-off

The UAV take-off can produce with help of inclined RDC also.

The UAV 5 is located on retaining pin 4, which fixates it's distantly $R$ from axis 1 to projection of the UAV 5 centre of mass on RDC 3 surface.

Onwards, at the command of the operator 12, through control unit 11 and an intercoupler 10 are started the UAV 5 engines and the engines 13 for RDC 3. At the same time operator 12, with account initial conditions of the UAV take-off, sets both an angular rotation speed of the fulcrum bearing 2 relatively axis "OY" and, accordingly, rigidly bound to him RDC 3, and direction of UAV flight after its separation from catapult.

In case of value $\omega_{\text {ygiv }}$ reaching, trigger mechanism of the retaining pin 4 operates at the command of block 11 and under action of centripetal force, which acts on UAV 5, his separation occurs from retaining pin 4 . Farther, UAV 5 makes a free flight at condition $R=R_{d}$ or, if $R<R_{d}$, with beginning is motion on RDC 3 and after this the free flight. 
The engines 13 turn off and rotation RDC is finished after UAV 5 separation from RDC 3.

On unmoving RDC upon the UAV will act weight force and support reaction. If RDC rotates, i.e. $\omega \neq 0$, upon the UAV will also acts the centripetal force $\left(F_{c p}\right)$, which is neutralized by force from support. The centripetal force, which acts upon UAV onto RDC at value linear velocity $V=$ const in the line of vector $\bar{R}$, is equal

$$
F_{c p}=m_{v} V^{2} / R
$$

where $m_{v}$ is the UAV mass.

It is known that the linear velocity value of an each RDC point is proportional to value of the RDC angular velocity $\omega_{d}$

$$
V=\omega_{d} \cdot R .
$$

It is follows from (1) - (2) that a value $F_{c p}$ is proportional to values of the radius $R$ and $\omega^{2}$, and a given magnitude of take-off velocity will achievement at RDC angular velocity

$$
\omega_{\text {ygiv }}=V_{t k} / R \text {. }
$$

It is follows from analysis (3) that at given value $V_{t k}$ it is necessary to increase magnitude $R$ for decreasing value $\omega_{\text {ygiv }}$. Besides, the UAV wingspan $L_{w}$, which can install on RDC is proportional a value $R$ at that it is rightly so next inequality

$$
R_{d} \geq L_{w} / 2 .
$$

At the same time, the value $R$ increasing adducts to an increasing of the RDC inertia moment.

As known that an inertia moments of the thin hard disk with radius $R$ and mass $m$ are equal $I_{y}=m R^{2} / 2$ and $I_{z}=I_{x}=m R^{2} / 4$, i.e. are proportional the value $R^{2}$.

Consequently, with an increase in the value of $R$, the requisite torque for the RDC increases also proportionally to $R^{2}$.

In this case also more integral-hp motors are necessary for lifting jacks.

The RDC construction at the UAV landing is shown in Fig. 4. This construction peculiarity is that the RDC 3 plane is turned relatively axes "OX" (or "OZ") on given angle $\alpha_{\text {giv }}$, which is equal the UAV angle attack on the trajectory its motion 15 (thin dashed line) at landing. Besides, rotation of the RDC 3 plane is required for an UAV having a roll angle $\gamma_{g i v}$ before landing [4].

The value $V_{\text {lan }}$, according (3), defines highest possible meaning of an RDC angular velocity at landing $\omega_{\text {lan }}$

$$
\omega_{\text {lan }}=V_{\text {lan }} / R_{\text {lan }},
$$

where $R_{\text {lan }}$ is the distance between the catapult fulcrum axis and the UAV landing spot, namely, the projection point of the UAV center mass on the RDC at the moment it touches the undercarriage.

The length of the UAV stopping distance 16 at its landing upon RC (thick dashed line) is defined: 1) a frictional coefficient between chassis and RDC surface; 2) a value $V_{\text {lan }}$ and, accordingly, a value $\omega_{\text {lan }}$; 3) a RDC degree of tilt. After undercarriage touching of RDC the UAV engine is turn off and a value $\omega_{\text {lan }}$ is beginning to decrease to zero.

At realization of the UAV take-off and landing method with help of RCS it follows to account its one important peculiarity. This peculiarity is due to the fact that during take-off and landing of UAVs using a flat horizontal surface of the RDC, the resultant sum of the vectors of the force of weight and centripetal force depends on the distance between of rotation axis and the UAV centre of mass only (Fig. 5). On the inclined RDC this resultant depends on the spatial position of the UAV also.

During rotation of the inclined RDC, the uneven load on the UAV structural elements can lead to their irreversible deformation or destruction.

At the same time at UAV landing on flat surface arise in desirable deformations of undercarriage tires (see Fig. 5).

When the flat rotating surface of the RDC is tilted by an angle $\xi$, the deformation of the chassis tires decreases (Fig. 6), but, in this case, due to the action of the centripetal force the normal component of the sum of the forces acting on the support is changed.

In Figures 5 and 6 the UAV fuselage is perpendicular to the vector $\bar{R}$. With another position of the UAV fuselage relative to the vector $\bar{R}$ during take-off from the RDC, difficulties arise in ensuring its stabilization in the initial part of the flight. Similarly, in the case of UAV landing on the RDC in the line of the collinear to vector $\bar{R}$, difficulties arise in ensuring the stabilization of an unmanned aircraft in the initial part of its movement on the RDC.

To determine the direction of the centripetal acceleration vector, it is possible use the spatial polar coordinate system (Fig. 7) centered at the intersection of the axis of rotation of the RDC with the plane of rotation of the UAV center of mass. The 
relations connecting the polar coordinates $\rho, \psi, \varphi$ and the rectangular coordinates $x, y, z$ have the form [5]:

$$
\begin{aligned}
& x=\rho \cos \psi \cos \varphi, \\
& y=\rho \cos \psi \sin \varphi, \\
& z=\rho \sin \psi,
\end{aligned}
$$

where $\rho, \psi, \varphi$ is the polar radius, longitude and latitude of the point $M$.

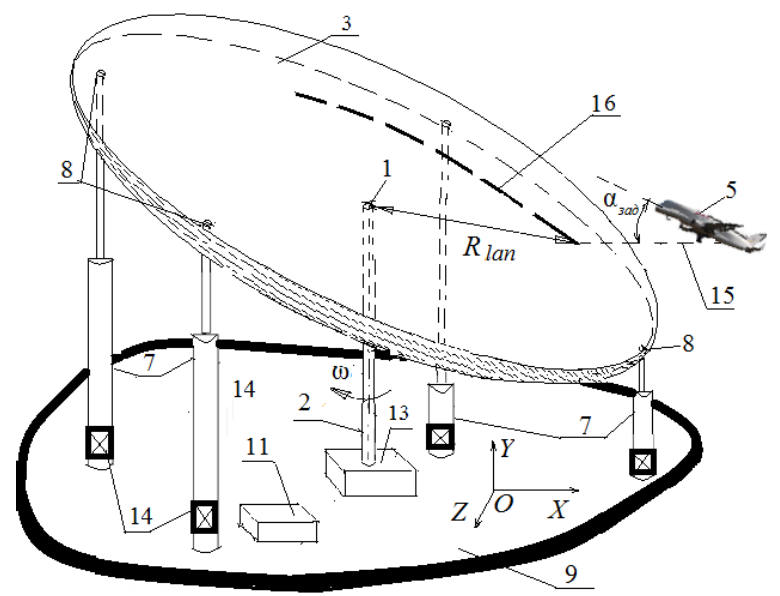

Fig. 4. The inclined position of the RDC at landing

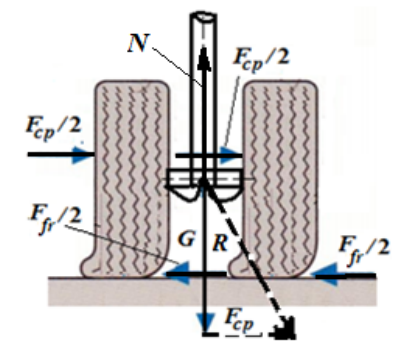

Fig. 5. The undercarriage tires on the horizontal surface, where $G$ is the UAV weight; $F_{f r}$ is the friction force; $N$ is the support reaction

\section{CALCULATION OF LANDING UAV TYPE} "ORBITER 3" ON THE ROTATING DISK OF A CATAPULT

Flight characteristics of the UAV type "Orbiter 3" are given in Table II.

TABLE II. Flight CHARACTERISTICS OF THE UAVTYPE "ORBITER 3"

\begin{tabular}{|l|c|c|}
\hline \multicolumn{1}{|c|}{ Name } & $\begin{array}{c}\text { Designation, } \\
\text { dimention }\end{array}$ & Value \\
\hline Takeoff mass, kg & $m$ & 20 \\
\hline Payload, kg & $P_{p}$ & 3 \\
\hline Wing span, $\mathrm{m}$ & $L_{w}$ & 3.6 \\
\hline Duration of the flight, hour & $T_{f}$ & $6-8$ \\
\hline Maximum speed $\mathrm{km} / \mathrm{h}$ & $V_{\max }$ & 140 \\
\hline
\end{tabular}

\section{A. The UAV landing in the direction perpendicular to vector $\bar{R}$}

Let the UAV is landing on the inclined rotating disk of the catapult (see Fig. 4) with a speed of $V_{L}==20 \mathrm{~m} / \mathrm{s}$ and with an angle of attack of $\xi=\alpha=$ $=0.25 \mathrm{rad}$. We also assume that the UAV center of mass, at the moment of its contact with the RDC, in the polar coordinate system is determined by the following initial data $\psi=0, \varphi=0, \rho=3 \mathrm{~m}$.

Height of the UAVs centre mass over the RDC will not be considered.

The value of the friction coefficient between the UAV chassis and the RDC surface both in the longitudinal and transverse directions is $f=0.35$.

It is assumed in the calculations, that the kinetic energy of the UAV is spent: 1) only on the work of friction forces (see Fig. 5), when it moves with equal deceleration on the RDC; 2 ) on the work of friction forces and the change in the potential energy of the UAV (Fig. 8).

At 1-st case the value of braking acceleration $\left(a_{b r}\right)$ at given initial data is $a_{b r}=(N \cos (0.25) f) / m$, i.e. $a_{b r}=(189.91 \cdot 0.35) / 20 \approx 3.32\left(\mathrm{~m} / \mathrm{s}^{2}\right)$, and the UAV braking time until it stops completely relative to the RDC is $t_{b r}=3.48 \mathrm{~s}$ at condition that during this time the UAV will move around a circle with a radius $R=3 \mathrm{~m}$ and parry, for example, at the cost of its own operating controls, centripetal force and overturning moment.

At 2-nd case the value $a_{b r}=[(N \cos (0.25) f)+$ $+G \sin (0.25)] / m$ is increased and is equal $a_{\text {br-sum }} \approx \approx 5.75\left(\mathrm{~m} / \mathrm{s}^{2}\right)$.

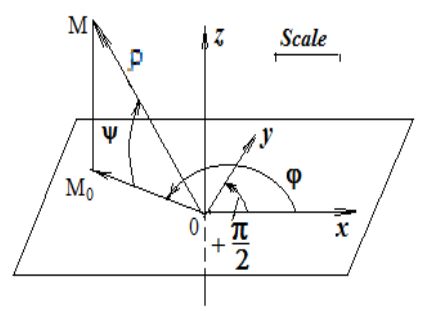

Fig. 7. Relationships between the polar and Cartesian coordinate systems

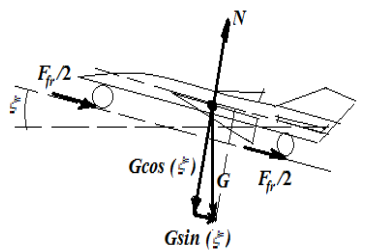

Fig. 8. The scheme of forces acting on the UAV in the plane "ZOY"
On unmoved RDC the braking distance at 1-st case is $120.36 \mathrm{~m}$, at 2-nd case is $69.61 \mathrm{~m}$. If, at the moment of UAV landing, the angular speed of the catapult disk rotation towards the moving UAV, according to (5), will be equal $\omega_{\text {ygiv }}=20 / 3 \approx 6.67(\mathrm{rad} / \mathrm{s})$, and then decrease to zero in $6.02 \mathrm{~s}$ and $3.48 \mathrm{~s}$, respectively, then the UAV will be unmoved on the RDC relative to the Earth. 
To reduce the braking time and braking distance, it is follows: 1) to direct the UAV speed vector at the time of landing towards the axis of the RDC rotation; 2) after the moment of landing, keep the direction of the UAV speed vector to the axis of the $\mathrm{RDC}$ rotation.

\section{$B$. The UAV landing in the direction collinear to vector $\bar{R}$}

If the angular velocity of the catapult's disk is relatively small, then it is possible to land the UAV in direction of the rotation axis of the RDC, while parrying the overturning UAV moment of forces using aerodynamic (or gas) rudders.

In this case, the centripetal force $F_{c p}$ will damp the landing speed of the UAV more actively. The calculated values of the centripetal force $\left(F_{c p}\right)$ and friction force $\left(F_{f r}\right)$ for three cases of UAV landing on the RDC, which are given in Table III, confirm this position. In Table III the value radius $R$ defines the distance between the UAV centre of mass and an axis of the RDC rotation at moment of landing.

As it follows from obtained calculations only one braking distance from Table 3 is satisfied necessary condition $s=4.14(\mathrm{~m})<5$. Otherwise, the UAV has not time to stop before an axis of the RDC rotation.

TABLE III. CALCULATED CHARACTERISTICS OF THE UAV LANDING ON THE RDC

\begin{tabular}{|l|l|l|l|}
\hline \multicolumn{1}{|c|}{ Radius $\boldsymbol{R}, \mathbf{m}$} & \multicolumn{2}{c|}{$\mathbf{3}$} & $\mathbf{5}$ \\
\hline An angular velocity $\omega_{d}, \mathrm{rad} / \mathrm{s}$ & 2 & 3 & 3 \\
\hline The centripetal force, $F_{c p}, \mathrm{n}$ & 240 & 540 & 900 \\
\hline The friction force, $F_{f r}, \mathrm{n}$ & 66.5 & 66.5 & 66.5 \\
\hline $\begin{array}{l}\text { The value acceleration, } a_{\text {sum }}, \\
\mathrm{m} / \mathrm{s}^{2}\end{array}$ & 15.32 & 30.32 & 48.32 \\
\hline The braking time, $t_{b r}, \mathrm{~s}$ & 1.31 & 0.66 & 0.41 \\
\hline The braking distance, $s, \mathrm{~m}$ & 13.05 & 6.6 & 4.14 \\
\hline
\end{tabular}

\section{CONCLUSIONS}

In the article is proposed the design of the rotational-catapult system for take-off and landing of UAVs and determined the algorithm of its functioning.

The features of the RCS operation with horizontal and inclined position of the catapult rotational disk are considered in detail.

The peculiarities of the RCS functioning include the fact that, on the one hand, the wing span of the UAV is limited by the size of the RDC, and an increase in the size of which leads to increased consumption of materials, energy costs, and etc.

On the other hand, structural elements of the wing and the UAV as a whole, depending on their distance from the axis of rotation of the airborne aircraft and their spatial position, will be affected by centripetal forces of different magnitude and direction, which can damage these elements.

The above calculations demonstrated the principle possibility of using a rotationally-catapult system for the UAV take-off and landing.

\section{REFERENCES}

[1] G. S. Alenchenkov and A. E. Pushkarev, "Structural synthesis of mechanisms of starting devices for the unmanned aerial vehicle of small weight," Intellectual systems in production. No. 1 (19), 2012, pp. 5-11, (in Russian).

[2] Pat. Utility Model No 98396 RU, IPC B64F 1/06. Catapult/ G. S. Alenchenkov, A. E. Pushkarev. Declared 05/13/10; publ. 10/20/10, Bull. Number 29.

[3] O. N. Vasiliev, Copyright certificate USSR No. 23783, "A device in the form of a rotatable catapult for launching and landing aircraft," 10/31/1931.

[4] N. F. Tupitsyn, I. A. Stepanenko, E. I. Voloschenko, and S. S. Shildskyi, "The special case of operative programming method of flight route," Electronics and Control Systems, no.1 (43), 2015, pp. 36-41. https://doi.org/10.18372/1990-5548.43.8848

[5] http://scask.ru/c_book_agm.php?id=25

Received March 27, 2020.

Tupitsyn Nikolay. Candidate of Science (Engineering). Associate Professor.

Aviation Computer-Integrated Complexes Department, National Aviation University, Kyiv, Ukraine.

Education: Moscow Phisics-thechnical Institute, Moscow, Russia, (1975).

Research area: dynamic of flight, experimental methods of aerodynamic, aviation simulators.

Publications: 102.

E-mail: tupitsyn2@gmail.com

Stepanenko Illia. Master of Engineering.

Education: National Aviation University of Ukraine, Kyiv, (2014).

Research area: computer-integrated manufacturing processes.

Publication: 10.

E-mail: STEPANENKO.iLay@gMaiL.com 
М. Ф. Тупіцин, І. О. Степаненко. Обертально-катапультний пристрій для зльоту і посадки безпілотного літального апарату

У статті запропоновано конструкцію ротаційно-катапультної системи для зльоту та посадки безпілотного літального апарату та визначено алгоритм іiі функціонування. Докладно розглянуто особливості роботи ротаційно-катапультної системи із горизонтальним і нахиленим положенням обертового диска катапульти. Особливістю функціонування ротаційно-катапультної системи $\epsilon$ те, що, 3 одного боку, розмір крила безпілотного літального апарату обмежений розмірами обертового диска катапульти, а збільшення його розмірів призводить до збільшення споживання матеріалів, витрат енергії, тощо. 3 іншого боку, на конструктивні елементи крила і безпілотний літальний апарат в цілому, в залежності від їх відстані до осі обертання катапульти і просторового положення, будуть діяти доцентрові сили різної величини і напрямків, які можуть пошкодити ці елементи. У роботі отримано вираз для напрямних косинусів одиничного доцентрового вектора прискорення для стійкого обертового руху катапульти в їі довільному нахиленому положенні, що дає можливість спростити обчислення динаміки руху безпілотного літального апарату. У статті також наведено приклад обчислення посадки безпілотного літального апарату з характеристиками «Орбітер 3» на обертовий диск катапульти.

Ключові слова: обертально-катапультний пристрій; обертовий диск катапульти; ротаційно-катапультна система.

Тупіцин Микола Федорович. Кандидат технічних наук. Доцент.

Кафедра авіаційних комп’ютерно-інтегрованих комплексів, Національний авіаційний університет, Київ, Україна.

Освіта: Московський фізико-технічний інститут, Москва, Росія, (1975).

Напрям наукових досліджень: динаміка польоту, експериментальні методи аеродинаміки.

Кількість публікацій: 102.

E-mail: tupitsyn2@gmail.com

Степаненко Ілля Олександрович. Магістр.

Освіта: Національний авіаційний університет, Київ, Україна, (2014).

Напрям наукової діяльності: комп'ютерно-інтегровані технологічні процеси.

Кількість публікацій: 10.

E-mail: STEPANENKO.iLay@gMaiL.com

Н. Ф. Тупицин, И. А. Степаненко. Вращательно-катапультная система для взлета и посадки беспилотного летательного аппарата

В статье предложена конструкция вращательно-катапультной системы для взлета и посадки беспилотного летательного аппарата и определен алгоритм ее функционирования. Подробно рассмотрены особенности работы вращательно-катапультной системы с горизонтальным и наклонным положением вращающегося диска катапульты. К особенностям функционирования вращательно-катапультной системы относится то что, с одной стороны, размер крыла беспилотного летательного аппарата ограничен размерами вращающегося диска катапульты, а увеличение его размеров приводит к увеличению потребления материалов, затрат энергии и тому подобное. С другой стороны, на конструктивные элементы крыла и беспилотный летательный аппарат в целом, в зависимости от их расстояния до оси вращения катапульты и пространственного положения, будут действовать центростремительные силы различной величины и направления, которые могут повредить эти элементы. В работе получено выражение для направляющих косинусов единичного центростремительного вектора ускорения для устойчивого вращательного движения катапульты в ее произвольном наклонном положении, что дает возможность упростить вычисления динамики движения беспилотного летательного аппарата. В статье также приведен пример вычисления посадки беспилотного летательного аппарата с характеристиками "Орбитер 3" на вращающийся диск катапульты.

Ключевые слова: вращательно-катапультная система; вращающийся диск катапульты; вращательнокатапультная система.

Тупицин Николай Федорович. Кандидат технических наук. Доцент.

Кафедра авиационных компьютерно-интегрированных комплексов, Национальный авиационный университет, Киев, Украина.

Образование: Московский физико-технический институт, Москва, Россия, (1975).

Направление научной деятельности: динамика полета, экспериментальные методы аэродинамики.

Количество публикаций: 102.

E-mail: tupitsyn2@gmail.com

Степаненко Илья Александрович. Магистр.

Образование: Национальный авиационный университет, Киев, Украина, (2014).

Направление научной деятельности: компьютерно-интегрированные технологические процессы.

Количество публикаций: 10.

E-mail: STEPANENKO.iLay@gMaiL.com 